\title{
Alcohol consumption and factors associated with binge drinking among female university students of health area
}

\author{
Consumo de álcool e fatores associados ao binge drinking entre universitárias da área de saúde \\ Consumo de alcohol y factores asociados al binge drinking entre las universitarias de la salud
}

Ana Karina Rocha Hora Mendonça ${ }^{1}$

Carla Viviane Freitas de Jesus ${ }^{1}$ Maria Bernadete Galrão de Almeida

Figueiredo ${ }^{1}$

Daisy Pereira Valido ${ }^{1}$

Marco Antonio Prado Nunes ${ }^{2}$

Sonia Oliveira Lima ${ }^{1}$

1. Universidade Tiradentes.

Aracaju, Sergipe, Brazil.

2. Universidade Federal de Sergipe.

Aracaju, Sergipe, Brazil.
Corresponding author:

Ana Karina Rocha Hora Mendonça.

E-mail: anakarinahora@hotmail.com

Submitted on 06/16/2017.

Accepted on 10/20/2017.

DOI: 10.1590/2177-9465-EAN-2017-0096

\section{Abstract}

Objective: To evaluate the pattern of alcohol consumption and the prevalence and factors associated with binge drinking among university students of health-related courses in Aracaju, Sergipe, Brazil. Methods: A cross-sectional study was performed of 865 female students from two universities in the Brazilian Northeast. The instruments used were the AUDIT and a questionnaire used to collect sociodemographic data. The chi-square test and logistic regression were used, with statistical significance set at $p$-value $<0.05$. Results: Risky alcohol consumption was evidenced in $16.4 \%$, while the prevalence of binge drinking was $48.0 \%$. Binge drinking was strongly associated with drunk driving $(O R=12.24)$ and living in a conflicting family environment $(\mathrm{OR}=6.33)$. Binge drinking was a constant in students who engaged in fights, those who had problems with the law and among smokers. Conclusion: The high prevalence of risky alcohol consumption, binge drinking and the association of these with risky behaviors in students serve to guide future public policies on prevention.

Keywords: Alcohol Drinking; Women's Health; Students; Health Care.

\section{Resumo}

Objetivo: Avaliar o padrão de consumo alcoólico e a prevalência e fatores associados ao binge drinking entre universitárias da área de saúde em Aracaju/SE. Métodos: Estudo transversal com 865 estudantes do sexo feminino de duas universidades do Nordeste brasileiro. Os instrumentos foram o AUDIT e um questionário com características sociodemográficas. Empregou-se Qui-quadrado e regressão logística, com nível de significância de 0,05. Resultados: O consumo de risco foi evidenciado em $16,4 \%$, enquanto a prevalência do binge drinking foi de $48,0 \%$, e esteve mais fortemente associada com dirigir alcoolizada $(O R=12,24)$ e conviver em ambiente familiar conflituoso $(O R=6,33)$. O binge drinking foi constante entre as alunas que se envolveram em brigas com agressão física, problemas com a lei e entre tabagistas. Conclusão: A elevada prevalência do consumo de risco, binge drinking e a associação destes com comportamentos de risco entre as acadêmicas servem para orientar futuras políticas públicas preventivas.

Palavras-chave: Consumo de Bebidas Alcoólicas; Saúde da mulher; Estudantes; Atenção à Saúde.

\section{REsumen}

Objetivo: Evaluar el patrón de consumo de alcohol, la prevalencia y los factores asociados al binge drinking entre estudiantes universitarias en el área de salud en Aracaju/SE. Métodos: Estudio transversal con 865 mujeres estudiantes de dos universidades del Nordeste brasileño. Los instrumentos fueron el AUDIT y las características sociodemograficas. Se utilizó la Chi-cuadrada y regresión logística, con nivel de significancia de 0,05. Resultados: El patrón de consumo de riesgo se muestra en el 16,4\%, mientras que la prevalencia del binge drinking fue de $48,0 \%$ y fue también más fuertemente asociada con conducir en estado etílico $(O R=12,24)$ y vida familia conflictiva $(O R=6,33)$. La borrachera fue constante entre las estudiantes que participaron en peleas con agresión física o problemas con la ley y entre las fumadoras. Conclusión: La alta prevalencia de consumo de riesgo, binge drinking y su asociación con comportamientos de riesgos entre académicas sirven para orientar las futuras políticas públicas preventivas.

Palabras clave: Consumo de Bebidas Alcohólicas; Salud de la Mujer; Estudiantes; Atención a la Salud. 


\section{INTRODUCTION}

Of the psychoactive substances, alcohol is the most consumed in the world with young people who start university life presenting a significant increase in consumption. ${ }^{1}$ The greater autonomy and freedom of their acts allied to the independence gained by coming of age and, in many cases, associated with the fact that they have moved far away from their relatives, make university students exposed to alcohol consumption. ${ }^{2,3}$ In addition, the commemorative events they most often organize are associated with the consumption of alcoholic beverages that, in addition to impairing the academic performance of these individuals, can expose them to risky behavior such as drinking and driving, involvement in aggression, fights and road traffic accidents. ${ }^{4}$

In this context, the abusive use of alcohol by young people, including university students, is an important public health problem, as it represents a risk of injuries, including disability and death, of the user and of other members of society. ${ }^{5,6}$ Studies have shown a high prevalence of acute alcohol abuse, also called binge drinking or heavy episodic drinking, among young people. ${ }^{7-10}$ This pattern of risky alcohol consumption can be characterized by the consumption of large amounts of alcohol, that is, four or more doses of alcoholic beverages for women and five or more doses for men, on a single occasion regardless of the frequency of this consumption. In terms of alcoholic blood concentration, this is the equivalent to approximately $80 \mathrm{mg} / \mathrm{dL}$ $(0.08 \%)$ in the adult individual. ${ }^{11}$

Women are more vulnerable to the use of alcoholic beverages compared to men due to their lower weight and higher proportion of body fat, as well as the lower hepatic metabolism of alcohol. Thus, women reach higher blood alcohol concentrations than men for the same amount of alcohol ingested. ${ }^{12} \mathrm{~A}$ recent national representative survey found that women, especially younger women, are an at-risk population group for alcohol consumption and that they are drinking more noxiously. ${ }^{13}$

An alcohol consumption practice, which is even more dangerous for the individual's physical and mental health and that is common in young people, is acute alcohol intoxication inherent after the ingestion of ten or more doses of alcohol over a short period of time categorized as extreme levels of binge drinking. ${ }^{9}$ In Brazil, there is a shortage of epidemiological studies related to the consumption of alcoholic beverages and the practice of binge drinking, even at extreme levels.

In addition to binge drinking, the harmful use of alcohol and chronic alcohol dependence stand out as common practices of alcohol consumption. An acute and transient state of disturbance of consciousness and/or cognition due to alcohol intoxication occurs with binge drinking. Harmful or abusive use of alcohol can cause physical and psychic complications defined as a drinking pattern that harms and is a risk to health with social and economic consequences for the individual, the people around and society in general. Chronic alcoholism or dependence syndrome is characterized by a set of behavioral, cognitive and physiological phenomena that develop after repeated consumption of alcoholic beverages. $^{1}$

Among students of health area, the excessive consumption of alcohol deserves more attention, since this factor may negatively influence their future professional practice regarding their diagnostic and therapeutic skills. Furthermore, these future professionals will be role models for their patients in relation to the prevention of disease and promotion of good health. ${ }^{14}$

Alcohol abuse, albeit occasional, is a complex issue in respect to its economic, social and individual dimensions, and so it is necessary to have deep knowledge of this problem in order to design measures to prevent and control abuse of this drug. ${ }^{15}$

The objective of this research was to evaluate the pattern of alcohol consumption and the prevalence and factors associated with binge drinking of university students in health area in Aracaju, Sergipe, Brazil.

\section{METHODS}

An observational, cross-sectional, prospective and analytical study with a quantitative approach was carried out in Aracaju in the Brazilian Northeast. The population of Aracaju, the state capital of Sergipe, is approximately 571,149 inhabitants ${ }^{16}$ with this city being the main urban and university center of the state.

This research was carried out in two higher education institutions classified as universities in the state, one public and the other private. In order to select which of the nine health area would be evaluated, a random draw was made with equal probabilities for all the courses. Thus, the study population was made up of students from undergraduate courses in medicine, dentistry, nursing, physiotherapy and nutrition. In the next sample selection stage, the classes of the first and secondto-last academic years of each evaluated course were chosen in order to reduce the variability of the sample in relation to the theoretical-scientific knowledge acquired by the students during graduation.

During the data collection period, from December 2015 to April 2016, the archives of the two institutions had 1178 female students regularly enrolled in the said academic years of the courses in question. A conservative prevalence of $50 \%$, margin of error of $5 \%$ and $95 \%$ confidence interval were estimated. The minimum sample calculated using Pocock's formula ${ }^{17}$ was 1049 female university students.

The inclusion criteria for the sample were female students, aged 18 years or more present in the classroom at the time of data collection.

The data were collected on three different occasions (days and times) in each classroom involved by trained researchers who were periodically supervised during the study. The instruments were individually completed in the classroom according to the schedule established by the coordinators of the courses in the health-related areas in question. 
The data collection instruments were two structured and self-administered questionnaires. The Brazilian version of the Alcohol Use Disorders Identification Test (AUDIT), a questionnaire developed by the World Health Organization (WHO) was used to evaluate dependency, that is, the pattern of alcohol consumption. This questionnaire is composed of ten questions related to alcohol consumption and is used to evaluate alcohol consumption over the previous 12 months. It is recommended that any individual with an AUDIT score greater than or equal to eight is considered an at-risk alcohol consumer. Zero to seven points is classified as abstinence or low-risk consumption, from 8 to 15 points as a pattern of risky consumption, from 16 to 19 points as a pattern of harmful use and 20 points or more as possible alcohol dependence..$^{18}$

Furthermore, a questionnaire was used with self-reported information on independent variables to investigate the sociodemographic characteristics of the female university students. These variables included age, marital status, physical activity, smoking, religion, paid work, course and academic year, family environment, age of first alcohol consumption, parents' permissiveness to alcohol use, drunk driving, accepting a ride with a drunk driver, use of energy drinks, involvement in fights, illicit and controlled drugs and influence of advertising campaigns for alcoholic beverages. This questionnaire also contained indicators related to the dependent variable, binge drinking, and was capable of characterizing the individual as to the different levels of binge drinking according to the number of doses ingested (four, 10 or 15) and the time spent drinking these doses. The questionnaire was adapted from the VI National Survey on the Use of Psychotropic Drugs among Elementary and Middle School Students of Public and Private Education Networks in the 27 Brazilian State Capitals in 2010. ${ }^{19}$

Thirty female university students from health area not included in the main study participated in a pilot test in order to identify doubts regarding the completion of the instruments.

Systematized data were entered in a spreadsheet of the Statistical Package for the Social Sciences (SPSS) software version 16.0. The descriptive analysis of qualitative variables included frequencies and percentages and the means and standard deviations (SD) are reported for quantitative variables. The variable 'binge drinking' was dichotomized as yes and no. The chi-square test was used to test the association between binge drinking and the independent variables. At this stage, to evaluate the magnitude of the associations, variables with $p$-value $<0.10$ were included in multivariate logistic regression analysis. Statistically significant values were considered when the $p$-value was $<0.05$. The independent variables of religion and housing were dichotomized for inclusion in logistic regression models.

This research was approved on November 12, 2015, by the Research Ethics Committee of Tiradentes University (UNIT) (\# 1.383.959). All participants signed Informed Consent Forms.

\section{RESULTS}

Of the population sample of 1049 students enrolled in the first and second-to-last academic years of health area, 137 students were excluded as 102 were under 18 years old and 35 refused to participate. Thus, $865(82.5 \%)$ female university students participated in the study, $217(25.1 \%)$ from the state university and $648(74.9 \%)$ from the private university. In relation to the time of studying, 470 (54.3\%) attended the first academic year, while 395 (45.7\%) attended the penultimate academic year. Most participants were from the nursing and nutrition courses: $282(32.6 \%)$ and $266(30.8 \%)$ students, respectively.

The mean age of the students was 21.97 years $(S D=4.43)$. Most students (93.1\%) were single, Catholics (68.8\%), regularly attended religious services $(72.1 \%)$, lived with parents or relatives (74.4\%), non-smokers (99.2\%) and did not do paid work (82.2\%). Moreover, $51.6 \%$ practiced physical activities (Table 1 ).

Table 1. Sociodemographic profile and life habits of female students $(n=865)$ on health area in two universities in the state capital of Sergipe - Brazil, 2015-2016

\begin{tabular}{lcc}
\hline Characteristic & N & $\%$ \\
\hline Marital status & & \\
\hline Single & 800 & 93.1 \\
Married & 59 & 6.9 \\
\hline Religion & & \\
\hline Catholic & 590 & 68.8 \\
Spiritualist & 69 & 8.0 \\
Evangelical & 126 & 14.7 \\
Others & 73 & 8.5 \\
\hline Frequent worshiper & & \\
\hline Yes & 621 & 72.1 \\
No & 240 & 27.9 \\
\hline Residence & & \\
\hline Parents/Relatives & 643 & 74.4 \\
Student accommodation & 43 & 5.0 \\
Alone & 87 & 10.1 \\
Others & 91 & 10.5 \\
\hline Paid work & & \\
\hline Yes & 154 & 17.8 \\
No & 710 & 82.2 \\
\hline Physical activity & & \\
\hline Yes & 446 & 51.6 \\
No & 418 & 48.4 \\
\hline Smoker & & \\
\hline Yes & 7 & 0.8 \\
No & 99.2 \\
\hline & & \\
\hline & & \\
\hline & & \\
\hline & & \\
\hline
\end{tabular}


It was observed that 814 students $(95.0 \%)$ lived in a quiet family environment and that 845 (98.5\%) had not been physically assaulted by an adult member of the family in the previous month. The prevalence of alcohol consumption by the parents of students was $52.6 \%(n=451)$. More than half $(54.8 \%)$ of the parents of the students who drank alcohol were permissive to the consumption of alcohol by their daughters. Of the female university students who reported consuming alcoholic beverages, $34 \%$ ( $n=236$ ) used to do so together with energy drinks. Other risk behaviors, such as driving under the influence of alcohol and taking a ride with a drunk driver were denied by $92.2 \%$ and $79.7 \%$ of the total number of students interviewed, respectively. Over $90 \%$ of students denied involvement in fights or the use of other illicit or controlled drugs.

Just over half of the students $(50.2 \%)$ reported that they found advertising campaigns on alcoholic beverages attractive and $82 \%$ of them $(n=708)$ denied the desire to consume alcohol as a result of the television media.

The prevalence of alcohol consumption at least once in the students' lives was $79.7 \%(n=689)$ with the mean age of experimentation being 16.03 years $(S D=2.46)$. Among the students who consumed alcoholic beverages, commercial establishments were the most cited places where they acquired alcohol $(89.1 \%)$. In $71.5 \%$ of the cases, the drink was initially offered by friends and in $16.5 \%$, by relatives. In the previous 12 months, alcohol was consumed by $65.9 \%(n=566)$ of the students showing the current use of alcohol.

According to the AUDIT classification, 723 students (83.6\%) were classified as abstinent or low-risk consumers, while 142 (16.4\%) had problematic use of alcohol and were classified as risky consumers (Table 2 ).

Table 2. AUDIT classification of female students $(n=865)$ on health area in two universities in the state capital of Sergipe - Brazil, 2015-2016

\begin{tabular}{lcc}
\hline AUDIT & $\mathbf{N}$ & $\mathbf{\%}$ \\
\hline Abstinent/low-risk consumer & 723 & 83.6 \\
At-risk consumer & 119 & 13.8 \\
Harmful alcohol use & 11 & 1.3 \\
\hline Possible alcoholic dependence & 12 & 1.4 \\
\hline
\end{tabular}

Binge drinking was reported by $48.0 \%(n=374)$ of the interviewed students not including the $9.2 \%(n=80)$ of the participants who reported not remembering to have ever done this in their lifetimes (Table 3). This table also shows the prevalence of extreme levels of binge drinking, characterized by the consumption of 10 or more doses in a short time interval.

According to the analysis of multivariate logistic regression, several factors are significantly associated with binge drinking, that is, four or more doses of alcoholic beverages. These factors included marital status, paid work, family environment, alcohol
Table 3. Reported practice of different levels of binge drinking by female students $(n=865)$ on health area in two universities in the state capital of Sergipe - Brazil, 2015-2016

\begin{tabular}{lcc}
\hline Binge drinking & $\mathbf{N}$ & \% \\
\hline$\geq 4$ doses & 374 & 48.0 \\
$\geq 10$ doses & 115 & 13.4 \\
$\geq 15$ doses & 47 & 5.5 \\
\hline
\end{tabular}

consumption by parents, parents' permissiveness of students alcohol consumption, desire to consume alcohol due to television advertisements, alcohol use associated with energy drinks, drunk driving and accepting a ride with a drunk driver (Tables 4 and 5)

The multivariate analyzes presented in Tables 4 and 5 show that drunk driving and living in a conflicting family environment reported by the students were the variables that had the strongest correlations with binge drinking of four or more doses of alcohol in the two calculated models.

All students who reported involvement in physical aggression or problems with the law $(n=12)$, as well as those who reported smoking $(n=6)$ practiced binge drinking (four or more doses of alcohol).

\section{DISCUSSION}

Alcohol is the most commonly used psychotropic substance among Brazilian female university students and the excessive consumption of this drug causes several health problems, as well as social and economic problems for the country. ${ }^{20} \mathrm{~A}$ study comparing alcohol consumption between the sexes and the expectation of drinking of female university students in health area in Ribeirão Preto, revealed a high prevalence of binge drinking, regardless of the sex of the individual. ${ }^{21}$ In this study, the prevalence of alcohol consumption by students at least once in their lifetime was $79.7 \%$. This was similar to the rates observed among students of health area in the State University of Montes Claros, MG (74.9\%), ${ }^{4}$ among students aged 13 to 17 years in public schools in Uberlândia, MG $(80.9 \%)^{22}$ and in Mexican medical students aged 17 to 25 years $(71.9 \%) .{ }^{5}$ Prevalences of approximately $90 \%$ were found for alcohol use in the lives of university students in 27 Brazilian state capitals, ${ }^{23}$ in students of health sciences colleges in Maceió, Alagoas, ${ }^{24}$ and among medical students from the state of Minas Gerais. ${ }^{25}$ These data show the high consumption of alcohol among young students of both sexes, including university students of health sciences area. Alcohol consumption in this population deserves special attention due to the functions these individuals will have with their patients after graduation such as transmitting their knowledge about health care and often serving as an example of conduct.

The mean age of starting to drink alcohol was 16.03 years, which is lower than that the legal age for the sale and consumption of alcoholic beverages in Brazil. Other studies with female 
Table 4. Logistic regression model adjusted for the general characteristics associated with binge drinking by female students $(n=374)$ on health area in two universities in the state capital of Sergipe - Brazil, 2015-2016

\begin{tabular}{|c|c|c|c|c|}
\hline \multirow[b]{2}{*}{ Characteristic } & \multicolumn{4}{|c|}{ Binge drinking ( $\geq 4$ doses) } \\
\hline & n (\%) & $\begin{array}{l}\text { Gross OR* } \\
(95 \% \mathrm{Cl})\end{array}$ & $\begin{array}{l}\text { Adjusted OR** } \\
(95 \% \mathrm{Cl})\end{array}$ & $p$-value $* * *$ \\
\hline \multicolumn{5}{|l|}{ Marital status } \\
\hline Single & 353 (94.9) & $1.77(0.10-3.16)$ & $3.20(1.32-7.80)$ & 0.010 \\
\hline Married & $19(5.1)$ & 1.00 & 1.00 & \\
\hline \multicolumn{5}{|l|}{ Academic years } \\
\hline First & $181(48.4)$ & 1.00 & 1.00 & \\
\hline Second-to-last & $193(51.6)$ & $1.63(1.23-2.17)$ & --- & 0.001 \\
\hline \multicolumn{5}{|l|}{ Religion } \\
\hline Catholic & $270(72.2)$ & $1.40(1.03-1.90)$ & --- & 0.030 \\
\hline Others & $104(27.8)$ & 1.00 & 1.00 & \\
\hline \multicolumn{5}{|c|}{ Frequent worshiper } \\
\hline Yes & $248(66.5)$ & 1.00 & 1.00 & \\
\hline No & $125(33.5)$ & $1.83(1.33-2.51)$ & --- & $<0.001$ \\
\hline \multicolumn{5}{|l|}{ Physical activity } \\
\hline Yes & $214(57.2)$ & $1.51(1.14-2.00)$ & --- & 0.005 \\
\hline No & $160(42.8)$ & 1.00 & 1.00 & \\
\hline \multicolumn{5}{|l|}{ Paid work } \\
\hline Yes & $75(20.1)$ & $1.42(0.98-2.06)$ & $2.45(1.38-4.37)$ & 0.002 \\
\hline No & 298 (79.9) & 1.00 & 1.00 & \\
\hline \multicolumn{5}{|c|}{ Family environment } \\
\hline Calm & 340 (91.9) & 1.00 & 1.00 & \\
\hline Conflicting & $30(8.1)$ & $3.48(1.68-7.22)$ & $6.33(1.77-22.60)$ & 0.004 \\
\hline \multicolumn{5}{|c|}{$\begin{array}{l}\text { Physical aggression by an adult family } \\
\text { member in the previous month }\end{array}$} \\
\hline Yes & $9(2.4)$ & $3.29(0.88-12.24)$ & --- & \\
\hline No & $365(97.6)$ & 1.00 & 1.00 & \\
\hline \multicolumn{5}{|c|}{ Alcohol consumption be parents } \\
\hline Yes & $241(64.4)$ & $2.41(1.81-3.22)$ & $1.55(1.03-2.33)$ & 0.034 \\
\hline No & $133(35.6)$ & 1.00 & 1.00 & \\
\hline \multicolumn{5}{|c|}{ Permissive parents } \\
\hline Yes & $240(64.2)$ & $2.37(1.72-3.27)$ & $2.03(1.35-3.05)$ & 0.001 \\
\hline No/Indifferent & $134(35.8)$ & 1.00 & 1.00 & \\
\hline
\end{tabular}

university students also detected early ages for experimenting

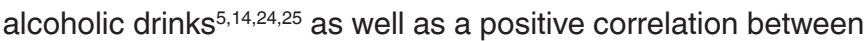
binge drinking and the start of alcohol use before entering higher education. ${ }^{25}$ Research carried out among female university students from the south of the country found that more than $90 \%$ of those who consumed alcoholic beverages, started drinking before entering university. ${ }^{20}$ This fact draws attention to the need to implement educational and preventive measures starting at high school in an attempt to reduce the problem of alcohol consumption at an early age.

In the present study, $34.1 \%$ of the students reported abstinence from alcohol, while $65.9 \%$ had consumed alcoholic beverages within the previous year. Studies that used the same instruments to measure alcohol consumption among female 
Table 5. Logistic regression model adjusted for contextual factors associated with binge drinking by female students $(n=374)$ on health area in two universities in the state capital of Sergipe - Brazil, 2015-2016

\begin{tabular}{|c|c|c|c|c|}
\hline \multirow[b]{2}{*}{ Characteristic } & \multicolumn{4}{|c|}{ Binge drinking ( $\geq 4$ doses) } \\
\hline & n (\%) & $\begin{array}{l}\text { Gross OR* } \\
(95 \% \mathrm{Cl})\end{array}$ & $\begin{array}{l}\text { Adjusted OR** } \\
(95 \% \mathrm{Cl})\end{array}$ & $p$-value*** \\
\hline \multicolumn{5}{|c|}{ View on advertising campaigns } \\
\hline Attractive & $214(57.2)$ & $1.62(1.22-2.15)$ & --- & 0.001 \\
\hline Not attractive & $160(42.8)$ & 1.00 & 1.00 & \\
\hline \multicolumn{5}{|c|}{$\begin{array}{l}\text { Desire to consume alcohol due } \\
\text { to television media }\end{array}$} \\
\hline Yes & $102(27.3)$ & $3.23(2.18-4.79)$ & $1.74(1.04-2.89)$ & 0.034 \\
\hline No & $272(72.7)$ & 1.00 & 1.00 & \\
\hline \multicolumn{5}{|c|}{ Use of energy drinks } \\
\hline Yes & $161(43.9)$ & $3.73(2.54-5.48)$ & $3.37(2.15-5.30)$ & $<0.001$ \\
\hline No & $206(56.1)$ & 1.00 & 1.00 & \\
\hline \multicolumn{5}{|c|}{ Drive under the influence } \\
\hline Yes & $59(15.8)$ & $18.64(6.70-51.86)$ & $12.24(3.41-43.92)$ & $<0.001$ \\
\hline No & $315(84.2)$ & 1.00 & 1.00 & \\
\hline \multicolumn{5}{|c|}{ Accept lift from drunk driver } \\
\hline Yes & $132(35.4)$ & $7.08(4.59-10.92)$ & $4.18(2.36-7.40)$ & $<0.001$ \\
\hline No & $241(64.6)$ & 1.00 & 1.00 & \\
\hline \multicolumn{5}{|c|}{$\begin{array}{l}\text { Involved in traffic accidents as } \\
\text { driver of the vehicle }\end{array}$} \\
\hline Yes & $22(5.9)$ & $2.04(1.00-4.19)$ & --- & 0.051 \\
\hline No & $352(94.1)$ & 1.00 & 1.00 & \\
\hline \multicolumn{5}{|c|}{ Use of other drugs } \\
\hline Yes & $28(7.5)$ & $5.37(2.20-13.12)$ & --- & $<0.001$ \\
\hline No & $346(92.5)$ & 1.00 & 1.00 & \\
\hline \multicolumn{5}{|c|}{ Use of controlled medications } \\
\hline Yes & $40(10.7)$ & $2.18(1.26-3.78)$ & --- & 0.005 \\
\hline No & $334(89.3)$ & 1.00 & 1.00 & \\
\hline
\end{tabular}

* OR: Odds Ratio; ** 95\% Cl: 95\% confidence interval; *** $p$-value - derived from logistic regression with Odds Ratio.

university students in Minas Gerais, obtained similar results to the current study: $36.4 \%$ of abstinence and $63.6 \%$ of alcohol consumption among medical students ${ }^{26}$ and $71.5 \%$ of regular alcohol consumption among health sciences students. ${ }^{8}$ In Mexico, medical students also presented a prevalence of alcohol consumption $(62.3 \%)^{5}$ similar to that observed here in Aracaju. Among students from the State University of Santa Cruz, in Ilhéus, Bahia ${ }^{27}$ also in the Brazilian Northeast, the prevalence of drinking alcoholic beverages was lower $(41.3 \%)$ than in the current study; the difference of these results is probably due to the use of a different instrument to measure alcohol consumption. Although these studies were carried out with students from areas related to healthcare and disease, there was a high prevalence of alcohol consumption even though they know the harmful effects of alcohol.

With regard to the pattern of alcohol consumption, $16.4 \%$ of female university students were classified as at-risk consumers and $83.6 \%$ as abstinent or low-risk consumers. Research conducted with medical students in the southeast of Brazil found $25.2 \%$ of at-risk alcohol consumers and $74.8 \%$ of abstinent or low-risk consumers. ${ }^{26}$ The highest percentage of alcohol consumption at problematic levels was found in Mexican medical students $(46.0 \%) .{ }^{5}$ In the latter two studies, the prevalence of at-risk use was higher than the present study probably because male students were included in the samples. In general, it is reported that men drink more than women. ${ }^{23,27}$ Considering 
the negative affect of the misuse of alcoholic beverages on the vulnerability of women, there is an urgent need for interventions and educational measures that address the inappropriate use of alcohol and its deleterious effects in the university context. Moreover, support groups should be formed for students who are using alcohol in a problematic way.

In the present investigation, the practice of binge drinking was identified in $374(48.0 \%)$ students. National and international literature deals with high prevalences of binge drinking among female university students. ${ }^{10,21,23}$ In studies carried out with university students on health area in the northern region of Minas Gerais State, binge drinking was observed in approximately $15 \%$ of the participants ${ }^{4,8}$ however the instrument used by these two surveys to measure binge drinking differed from that used in the present study. A representative national survey among university students pointed out the existence of a tendency of women to increase alcohol consumption. ${ }^{23}$ This may be due to the incessant search for gender equality promoted by postmodernity, which has reduced discrimination and increased social acceptance of the consumption of alcohol by women. These results show the exposure of this population group to binge drinking and the importance of developing targeted preventive programs that reduce social and health impairment.

This study revealed that at least once in their lifetimes, $13.4 \%$ of female university students drank ten or more doses as binge drinking and that $5.5 \%$ had ingested fifteen or more doses of alcohol within a short time interval. A study of a representative sample of high school students in the United States, with a mean age of 18 years, found prevalences of $10.5 \%$ of binge drinkers who had ingested ten or more doses and $5.6 \%$ who had ingested 15 or more doses ${ }^{9}$ similar to the results found here in Aracaju. These data show that binge drinking is practiced at high levels by a significant proportion of students of both high schools and colleges. This situation is of concern because of the negative consequences of accidents and injuries caused by binge drinking and the possibility of long-term health problems.

In relation to the family, a possible factor influencing the use of drugs among adolescents, ${ }^{28,29}$ this study found that a large number of the students' parents were permissive to the use of alcohol (54.8\%) and consumed alcoholic beverages themselves (52.6\%). According to the adjusted logistic regression analysis of this study, a correlation was observed between binge drinking both with parents' permissiveness to female university students' alcohol consumption $(\mathrm{OR}=2.03)$ and their own alcohol consumption $(\mathrm{OR}=1.55)$. This parental behavior may be related to the high prevalence of alcohol consumption of these young women who, in addition to their parents' example and the permissive family environment, also have greater freedom and lack of supervision in the university environment.

The current research found that the great majority of the students $(95.0 \%)$ reported living in a quiet family environment. Of those living in an environment of family conflict, $75.0 \%$ reported having practiced binge drinking, demonstrating the existence of a strong correlation between this type of environment and the acute abuse of alcoholic beverages by these young women $(\mathrm{OR}=6.33)$. Similarly, risky alcohol use among adolescent students from Uberlândia, MG was associated with conflict within the family environment of these individuals. ${ }^{22}$ Studies indicate that most families of adolescent substance abusers and addicts have characteristics such as family ties in conflict, lack of closeness between family members, lack of a well-defined hierarchy and parents who do not give a positive example in respect to drug use. ${ }^{28}$ These results show that family dysfunctions influence alcohol consumption, especially in the adolescent and academic phases. Because it is a modifiable risk factor, adequate guidance to strengthen family relationships and to change the less liberal attitudes of parents regarding the use of alcohol by their children may reduce disorders caused by the misuse of this drug among young people.

Of the total number of students evaluated in this study, slightly more than half $(50.2 \%)$ reported that they found advertisements for alcoholic beverages attractive, while the majority $(82.0 \%)$ reported that they did not feel like drinking alcohol after watching ads. According to the adjusted logistic regression analysis, students who wished to consume alcohol as a result of television media had a 1.74 times greater chance of binge drinking compared to students who denied the desire to drink alcohol after seeing commercials. The association between feeling the desire to drink after watching advertisements for alcoholic beverages and alcohol use in life was observed in a survey of 638 teenagers from a Brazilian countryside city. ${ }^{22}$ The literature points to the existence of a causal relationship between advertising and alcohol consumption, since interest in the advertisement increases the desire and the intention to buy alcohol. ${ }^{30}$ The fact that the word 'drug' is rarely used for alcohol facilitates its acceptance and advertising through commercials that aim to associate the product with appealing images and happy and enjoyable situations. ${ }^{31}$ It is believed that regulations directed against unrestrained freedom of this type of media could reduce the inadequate consumption of alcohol within society and especially by the young during their development phase.

A low prevalence of smoking was detected $(0.8 \%)$ in this study, which corroborates the findings of studies with female university students from the northeastern region of Brazil..27,32 Among the female students who reported smoking, binge drinking was a constant. Health promotion campaigns, such as public anti-smoking policies, increase quality of life and reduce health risks related to its determinants and conditions. ${ }^{33}$ The high prevalence of non-smoking students observed in this study may be due to the positive influence and the effectiveness of anti-smoking policies with the positive association between alcohol consumption and risk of tobacco use demonstrates the need for early interventions to reduce these practices among female university students. 
Although most of the students in the sample $(82.2 \%)$ did not have paid work and the average age of experimentation was less than 18 years of age, $89.1 \%$ of them reported buying alcoholic beverages at retail outlets. Thus, it is assumed that there is a disrespect for the law that prohibits the sale of alcoholic beverages to underage persons and that their parents or guardians may be contributing financially to the purchase of drink. According to the adjusted logistic regression analysis, binge drinking was more common in students who had paid work ( $\mathrm{OR}=2.45$ ) compared to those who did not work, as well as in single students $(O R=3.20)$ compared to married women. The financial autonomy of female university students revealed a positive association with binge drinking, although a high percentage of students who were economically dependent on their parents also drank alcohol regularly. Therefore, it is probable that better family financial control can reduce the use of alcoholic beverages among individuals in this age group.

Most of the students who reported the use of alcohol together with energy drinks $(78.5 \%)$ drank heavily $(\mathrm{OR}=3.37)$. Research carried out with female university students showed that energy drinks increase the desire to consume alcohol, as well as their susceptibility to binge drinking ${ }^{34}$ and alcohol dependence. ${ }^{35}$ It is necessary that preventive measures that address the use of alcohol among young people, also alert to the dangerous association of energy drinks, an indiscriminate practice.

In this research, all students who reported involvement in fights or in problems with the law practiced binge drinking. Other research with female university students of health area also showed an association between binge drinking and violent situations. ${ }^{4,8}$ In the present study, binge drinkers presented higher chances for other risk behaviors too, such as drunk driving $(O R=12.24)$ and taking a ride with a drunk driver $(O R=4.18)$. Research with university students from 27 Brazilian state capitals warns that the consumption of more alcohol doses increases the probability of engaging in risky road traffic behavior. ${ }^{23}$ The neuromotor changes caused by alcohol-induced euphoria, reduce attention, distort the perception of velocity and cause difficulty in discerning distinct lights. ${ }^{36}$ Binge drinking leads to the risk of car accidents and violence, ${ }^{1}$ which can result in the loss of life or incidents that lead to temporary or permanent debilitating sequelae at young ages and thus this constitutes a major public health problem.

This study presented limitations because most of the participants did not complete the Brazilian Association of Advertisers/Brazilian Association of Market Institutes (ABIPEME) questionnaire used to measure the individual's socioeconomic status. It is also possible that there was underreporting of alcohol abuse inherent to the fear of exposing this habit, which probably did not interfere in the results obtained due to the large sample size used in this study. The data of this research will allow comparisons with those of future studies that should evaluate female university students submitted to brief educational intervention strategies against excessive alcohol consumption, such as the Brief Alcohol Screening and Intervention for College Students (BASICS) intervention. ${ }^{37}$

\section{CONCLUSIONS}

In the city of Aracaju, in the period evaluated, the experimentation of alcoholic beverages by female university students on health area occurred at early ages and high prevalences of alcohol consumption and binge drinking were observed.

The results of this study indicated that single students, smokers and those with paid jobs are more likely to binge drink.

Factors that influenced binge drinking among female university students are commercial advertisements that encourage the consumption of alcoholic beverages and family environments marked by conflict, permissive parents and parents who consumer alcoholic beverages.

Significant risky behaviors associated with binge drinking in this population group are correlated to physical aggression and problems with the law, the use of energy drinks in association with alcohol, drunk driving and accepting a lift with a drunk driver.

Alcohol consumption among adolescents who have not entered higher education, since they reported experimentation while they were still underage, and while in the academic world, require healthcare measures. The implementation of programs that educate students about the physical and psychosocial damage caused by the problematic use of alcohol can guide them in the responsible consumption of alcoholic beverages.

\section{REFERENCES}

1. World Health Organization. Global status report on alcohol and health 2014. Geneva: World Health Organization; 2014. 392 p.

2. Baumgarten LZ, Gomes VLO, Fonseca AD. Consumo alcoólico entre universitários(as) da área da saúde da Universidade Federal do Rio Grande/RS: subsídios para enfermagem. Esc Anna Nery [Internet]. Sep 2012; [cited 2017 Mar 20]; 16(3):530-5. Available from: http://www.scielo.br/scielo.php?script=sci_arttext\&pid=S1414$81452012000300015 \&$ Ing $=$ en\&nrm=iso\&tlng $=p t$

3. Haas AL, Smith SK, Kagan K, Jacob T. Pre-college pregaming: practices, risk factors, and relationship to other indices of problematic drinking during the transition from high school to college. Psychol Addict Behav [Internet]. 2012 Dec; [cited 2017 Mar 20];26(4):931-8. Available from: http://www.ncbi.nlm.nih.gov/pubmed/23088409. DOI: 10.1037/ a0029765

4. Cardoso FM, Barbosa HA, Costa FM, Vieira MA, Caldeira AP. Fatores associados à prática do binge drinking entre estudantes da área da saúde. Rev CEFAC [Internet]. 2015 Mar/Apr; [cited 2017 Mar 20];17(2):475-84. Available from: http://www.scielo.br/scielo. php?script=sci_arttext\&pid=S1516-18462015000200475\&lng=pt\&nr $m=$ iso\&tlng=en

5. Puig-Nolasco A, Cortaza-Ramirez L, Pillon SC. Consumo de alcohol entre estudiantes mexicanos de medicina. Rev Latino Am Enferm [Internet]. 2011 Jun; [cited 2017 Mar 20]; 19(no.spe):714-21. Available from: http://www.scielo.br/scielo.php?script=sci_arttext\&pid=S010411692011000700008\&lng=es\&nrm=iso\&tlng=es. DOI: 10.1590/ S0104-11692011000700008 
6. Gonçalves PD, Cunha PJ, Malbergier A, do Amaral RA, de Oliveira LG, Yang JJ, et al. The association between low alcohol use and traffic risk behaviors among Brazilian college students. Alcohol [Internet]. 2012 Nov; [cited 2017 Mar 20]; 46(7):673-9. Available from: https://www.ncbi. nlm.nih.gov/pubmed/22921955. DOI: 10.1016/j.alcohol.2012.08.002

7. Chavez PR, Nelson DE, Naimi TS, Brewer RD. Impact of a new genderspecific definition for binge drinking on prevalence estimates for women. Am J Prev Med [Internet]. 2011 Apr; [cited 2017 Mar 20]; 40(4):468-71. Available from: http://www.ncbi.nlm.nih.gov/pubmed/21406282. DOI: 10.1016/j.amepre.2010.12.008

8. Nunes JM, Campolina LR, Vieira MA, Caldeira AP. Consumo de bebidas alcoólicas e prática do binge drinking entre acadêmicos da área da saúde. Rev Psiquiatr Clín [Internet]. 2012; [cited 2017 Mar 20]; 39(3):94-9. Available from: http://www.scielo.br/scielo.php?script=sci_ arttext\&pid=S0101-60832012000300005\&lng=pt\&nrm=iso\&tlng=en

9. Patrick ME, Schulenberg JE, Martz ME, Maggs JL, O'Malley PM, Johnston LD. Extreme binge drinking among 12th-grade students in the United States: prevalence and predictors. JAMA Pediatr [Internet]. 2013 Nov; [cited 2017 Mar 20]; 167(11):1019-25. Available from: http://www.ncbi.nlm.nih.gov/pubmed/24042318. DOI: 10.1001/ jamapediatrics.2013.2392

10. Tavolacci MP, Boerg E, Richard L, Meyrignac G, Dechelotte P, Ladner J. Prevalence of binge drinking and associated behaviours among 3286 college students in France. BMC Public Health [Internet]. 2016 Feb; [cited 2017 Mar 20]; 16:178. Available from: http://www.ncbi.nlm.nih. gov/pubmed/26905284. DOI: 10.1186/s12889-016-2863-x

11. National Institute on Alcohol Abuse and Alcoholism (NIAAA). Helping patients who drink too much: a clinician's guide. Bethesda: NIAAA;2005. $40 \mathrm{p}$.

12. Boyle P, Boffetta P, Lowenfels AB, Burns H, Brawley O, Zatonski W, et al. Alcohol: Science, Policy and Public Health. Oxford: Oxford University Press; 2013. 448 p.

13. Laranjeira R, org. II Levantamento Nacional de Álcool e Drogas (LENAD). São Paulo: Instituto Nacional de Ciência e Tecnologia para Políticas Públicas do Álcool e Outras Drogas (INPAD)/UNIFESP; 2014. 85 p.

14. Picolotto E, Libardoni LFC, Migott AMB, Geib LTC. Prevalência e fatores associados com o consumo de substâncias psicoativas por acadêmicos de enfermagem da Universidade de Passo Fundo. Ciên Saúde Coletiva [Internet]. May 2010; [cited 2017 Mar 20]; 15(3):645-54. Available from: http://www.scielo.br/scielo.php?script=sci_arttext\&pid=S1413$81232010000300006 \& \operatorname{lng}=p t \& n r m=i s o \&$ tlng=pt

15. Monteiro CFS, Araújo TME, Sousa CMM, Martins MCC, Silva LLL. Adolescentes e o uso de drogas ilícitas: um estudo transversal. Rev Enferm UERJ [Internet]. 2012 Jul/Sep; [cited 2017 Nov 14]; 20(3):3448. Available from: http://www.e-publicacoes.uerj.br/index.php/ enfermagemuerj/article/view/4105

16. Instituto Brasileiro de Geografia e Estatística (IBGE) (BR). Brasil. 2016 [cited 2017 Mar 20]. Available from: http://cod.ibge.gov.br/5NZ

17. Pocock SJ. Clinical Trials. A Practical Approach. Chichester:Wiley; 1996. $288 \mathrm{p}$.

18. Babor T, Higgins-Biddle JC, Saunders JB, Monteiro MG. The Alcohol Use Disorders Identification Test: Guidelines for use in primary care. Geneva: World Health Organization. [Internet]. 2001; [cited 2017 Mar 20]; p. 1-40. Available from: http://www.talkingalcohol.com/files/pdfs/ WHO_audit.pdf. DOI: 10.1177/0269881110393051

19. Carlini ELA, Noto AR, Sanchez ZVM, Carlini CMA, Locatelli DP, Abeid LR, et al. VI Levantamento Nacional sobre o Consumo de Drogas Psicotrópicas entre Estudantes do Ensino Fundamental e Médio das redes pública e privada de ensino nas 27 Capitais Brasileiras - 2010. São Paulo: Centro Brasileiro de Informações sobre Drogas PsicotrópicasCEBRID/UNIFESP/SENAD; 2010.506 p.

20. Ramis TR, Mielke GI, Habeyche EC, Oliz MM, Azevedo MR, Hallal PC. Tabagismo e consumo de álcool em estudantes universitários: prevalência e fatores associados. Rev Bras Epidemiol [Internet]. 2012 Jun; [cited 2017 Mar 20]; 15(2):376-85. Available from: http://www. scielosp.org/scielo.php?script=sci_arttext\&pid=S1415-790X2012000 200015\&lng=pt\&nrm=iso\&tlng=pt
21. Fachin A, Furtado EF. Uso de álcool e expectativas do beber entre universitários: uma análise das diferenças entre os sexos. Psicol Teor Pesq [Internet]. 2013 Oct/Dec; [cited 2017 Mar 20]; 29(4):421-8. Available from: http://www.scielo.br/scielo.php?script=sci_arttext\&pid $=$ S0102-37722013000400008

22. Reis TG, Oliveira LCM. Padrão de consumo de álcool e fatores associados entre adolescentes estudantes de escolas públicas em município do interior brasileiro. Rev Bras Epidemiol [Internet]. 2015 Jan/ Mar; [cited 2017 Mar 20]; 18(1):13-24. Available from: http://www.scielo. br/scielo.php?script=sci_arttext\&pid=S1415-790X2015000100013\&ln $\mathrm{g}=\mathrm{pt} \& \mathrm{nrm}=\mathrm{iso} \& \mathrm{t}$ Ing=en

23. Andrade AG, Duarte PCAV, Oliveira LG. I Levantamento nacional sobre o uso de álcool, tabaco e outras drogas entre universitários das 27 capitais brasileiras. Brasília: Secretaria Nacional de Políticas sobre Drogas - SENAD/FMUSP; 2010. $284 \mathrm{p}$.

24. Pedrosa AAS, Camacho LAB, Passos SRL, Oliveira RVC. Consumo de álcool entre estudantes universitários. Cad Saúde Pública [Internet] 2011 Aug; [cited 2017 Mar 20]; 27(8):1611-21. Available from: http:// www.scielosp.org/scielo.php?script=sci_arttext\&pid=S0102-311X201 1000800016\&lng=pt\&nrm=iso\&tlng=pt

25. Carneiro EB, Braga RT, Silva LFD, Nogueira MC. Fatores associados a beber pesado episódico entre estudantes de medicina. Rev Bras Educ Med [Internet]. 2012 Oct/Dec; [cited 2017 Mar 20]; 36(4):52430. Available from: http://www.scielo.br/scielo.php?script=sci arttext\&pid=S0100-55022012000600011\&lng=pt\&nrm=iso\&tlng=en

26. Rocha LA, Lopes ACFMM, Martelli DRB, Lima VB, Martelli-Júnior H Consumo de álcool entre estudantes de faculdades de Medicina de Minas Gerais, Brasil. Rev Bras Educ Med [Internet]. 2011 Jul/Sep; [cited 2017 Mar 20]; 35(3):369-75. Available from: http://www.scielo.br/scielo. php?script=sci_arttext\&pid=S0100-55022011000300010\&lng=pt\&nrm $=$ iso\&tlng=pt

27. De Sousa TF, José HPM, Barbosa AR. Condutas negativas à saúde em estudantes universitários brasileiros. Ciênc Saude Coletiva [Internet]. 2013 Dec; [cited 2017 Mar 20]; 18(12):3563-75. Available from: http:// www.scopus.com/inward/record.url?eid=2-s2.0-84888158719\&partne $\mathrm{rID}=40 \& \mathrm{md} 5=96 \mathrm{ffe}$ 074c8bfeadb1921aca09f79992b

28. Guimarães ABP, Hochgraf PB, Brasiliano S, Ingberman YK. Aspectos familiares de meninas adolescentes dependentes de álcool e drogas. Rev Psiquiatr Clín [Internet]. 2009; [cited 2017 Mar 20]; 36(2):6974. Available from: http://www.scielo.br/scielo.php?script=sci_ arttext\&pid=S0101-60832009000200005\&lng=pt\&nrm=iso\&tlng=pt

29. Cavalcante MBPT, Alves MDS, Barroso MGT. Adolescência, álcool e drogas: uma revisão na perspectiva da promoção da saúde. Esc Anna Nery Rev Enferm [Internet]. 2008 Sep; [cited 2017 Mar 20]; 12(3):555-9. Available from: http://www.scielo.br/pdf/ean/v12n3/v12n3a24

30. Pinsky I, El Jundi SARJ. O impacto da publicidade de bebidas alcoólicas sobre o consumo entre jovens: revisão da literatura internacional. Rev Bras Psiquiatr [Internet]. 2008 Dec; [cited 2017 Mar 20]; 30(4):36274. Available from: http://www.scielo.br/scielo.php?script=sci arttext\&pid=S1516-44462008000400012\&lng=pt\&nrm=iso\&tlng=en

31. Acselrad G, Karam ML, David HMSL, Alarcon S, Pfeil FMC, Andrade CSGCD. Consumo de Bebidas Alcoólicas no Brasil: Estudo com base em fontes secundárias. Rio de Janeiro: Faculdade Latinoamericana de Ciências Sociais; 2012. 162 p.

32. Granville-Garcia AF, Sarmento DJS, Santos JA, Pinto TA, Sousa RV, Cavalcanti AL. Smoking among undergraduate students in the area of health. Ciênc Saúde Coletiva [Internet]. 2012 Feb; [cited 2017 Mar 20]; 17(2):389-96. Available from: http://www.scielosp.org/scielo. php?script=sci_arttext\&pid=S1413-81232012000200013\&Ing=en\&n $\mathrm{m}=$ iso\&tIng=en. DOI: 10.1590/S1413-81232012000200013

33. Ministério da Saúde (BR). Secretaria de Vigilância em Saúde, Secretaria de Atenção à Saúde. Política Nacional de Promoção da Saúde. $3^{\underline{a}}$ ed. Brasília (DF): Ministério da Saúde; 2010.

34. Velazquez CE, Poulos NS, Latimer LA, Pasch KE. Associations between energy drink consumption and alcohol use behaviors among college students. Drug Alcohol Depend [Internet]. 2012 Jun; [cited 2017 Mar 20]; 123(1-3):167-72. Available from: http://www.ncbi.nlm.nih.gov/ pubmed/22138539. DOI: 10.1016/j.drugalcdep.2011.11.006 
35. Marczinski CA, Fillmore MT, Henges AL, Ramsey MA, Young CR. Mixing an energy drink with an alcoholic beverage increases motivation for more alcohol in college students. Alcohol Clin Exp Res [Internet]. 2013 Feb; [cited 2017 Mar 20]; 37(2):276-83. Available from: http:// www.ncbi.nlm.nih.gov/pubmed/22724427. DOI: 10.1111/j.15300277.2012.01868.x
36. Moura EC, Malta DC, Morais Neto OL, Penna GO, Temporão JG. Direção de veículos motorizados após consumo abusivo de bebidas alcoólicas, Brasil, 2006 a 2009. Rev Saúde Pública [Internet]. 2009 Oct [cited 2017 Mar 20]; 43(5):891-4. Available from: http://www.scielo.br/ scielo.php?script=sci_arttext\&pid=S0034-89102009000500021\&lng =pt\&nrm=iso\&tlng=en

37. Dimeff LA, Baer JS, Kivlahan DR, Marlatt GA. Alcoolismo entre estudantes universitários: uma abordagem de redução de danos. São Paulo: Editora Unesp; 2002. 231 p. 